\title{
ASPEK HUMANISTIK PEMBELAJARAN MATEMATIKA DISKRIT DAN KARAKTER TANGGUNG JAWAB MAHASISWA (STUDI KASUS DI AMIK PGRI KEBUMEN)
}

\author{
Nur Wasito ${ }^{\mathrm{a}}$ \\ ${ }^{a}$ Dosen Program Studi Manajemen Informatika, AMIK PGRI Kebumen, \\ Jl. Kaswari no 26 Kebumen \\ scientistmuda86@gmail.com
}

\begin{abstract}
ABSTRAK
Tujuan penelitian ini untuk mendeskripsikan aspek humanistik perangkat pembelajaran dan proses pembelajaran matematika diskrit program studi manajemen informatika AMIK PGRI Kebumen, serta mendeskripsikan karakter tanggung jawab mahasiswa. Target khusus adalah: (1) mengetahui perangkat pembelajaran (silabus, satuan acara perkuliahan, bahan ajar dan soal tes) yang digunakan (2) mengetahui proses pembelajaran yang dilakukan dosen dan mahasiswa (3) mengetahui karakter tanggung jawab mahasiswa. Objek utama penelitian kualitatif ini adalah mahasiswa dan dosen pengampu mata kuliah matematika diskrit program studi manajemen informatika AMIK PGRI Kebumen. Metode yang digunakan dalam penelitian ini adalah observasi, wawancara dan dokumentasi. Aspek humanistik pada perangkat pembelajaran dan proses pembelajaran masuk dalam kategori tinggi, begitu juga dengan karakter tanggung jawab mahasiswa masuk dalam kategori tinggi.
\end{abstract}

Kata kunci: humanistik, matematika diskrit, karakter, tanggung jawab.

\begin{abstract}
The objective of this study is to describe humanistic aspect on learning media and mathematical learning process of information management AMIK PGRI Kebumen and to describe students' responsible character. The specific targets are: (1) to determine the learning media used (syllabus, lesson plan, teaching material, tes) (2) to determine the learning process conducted by lecturer and students (3) to know students' responsible character. The main object of this qualitative study was students and lecturer who taught discrete mathematics in information management AMIK PGRI Kebumen. Methods used in this study were observation, interview and documentation. Humanistic aspects on the learning media and learning process categorized as high, as well as students' responsible character in high category.
\end{abstract}

Keywords: humanistic, discrete mathematics, character, responsible.

\section{Pendahuluan}

Salah satu tujuan pendidikan tinggi dalam UU No. 12 tahun 2012 adalah berkembangnya potensi mahasiswa agar menjadi manusia yang beriman dan bertaqwa kepada Tuhan
Yang Maha Esa dan berakhlak mulia, sehat, berilmu, cakap, kreatif, mandiri, terampil, kompeten dan berbudaya untuk kepentingan bangsa.

Pendidikan sendiri merupakan proses interaksi, di dalamnya terdapat 
kegiatan interaksi yang melibatkan pendidik dan peserta didik. Menurut Dimyati dan Mudjiono (2006), tindakan mendidik tersebut tertuju pada perkembangan peserta didik agar menjadi mandiri. Untuk dapat berkembang menjadi mandiri, peserta didik harus dapat belajar. Bila peserta didik belajar, maka akan terjadi perubahan mental pada diri peserta didik tersebut. Oleh karenanya, unsur-unsur proses belajar memegang peranan yang penting dalam proses pembelajaran yang melibatkan pendidik dengan peserta didik.

Budiningsih (2005) berpendapat bahwa proses belajar hendaknya dimulai dan ditujukan untuk kepentingan memanusiakan manusia itu sendiri. Hal ini menunjukkan aspek humanistik merupakan aspek yang penting dalam setiap proses pembelajaran.

Junaedi dan Asikin (2012) mengungkapkan bahwa pada saat implementasi pembelajaran humanistik, aktivitas peserta didik terlihat dalam kondisi baik yang ditunjukkan dengan terlatihnya peserta didik sebagai penemu, bukan hanya penerima fakta-fakta dan prosedur-prosedur, peserta didik memperolah kesempatan belajar untuk saling membantu dan dapat belajar berbagai macam cara dalam menyelesaikan masalah.
Menurut Rogers (Dalyono, 2012) ada sejumlah prinsip-prinsip pembelajaran humanistik yang penting, diantaranya ialah:

1) Manusia itu mempunyai kemampuan untuk belajar secara alami.

2) Belajar yang signifikan terjadi apabila subject matter dirasakan peserta didik mempunyai relevansi dengan maksud-maksudnya sendiri.

3) Belajar yang menyangkut suatu perubahan di dalam persepsi mengenai dirinya sendiri, dianggap mengancam dan cenderung ditolaknya.

4) Tugas-tugas belajar yang mengancam diri adalah lebih mudah dirasakan dan diasimilasikan apabila ancaman-ancaman dari luar itu semakin kecil.

5) Apabila ancaman terhadap diri peserta didik rendah, pengalaman dapat diperoleh dengan berbagai cara yang berbeda-beda dan terjadilah proses belajar.

6) Belajar yang bermakna diperoleh peserta didik dengan melakukannya.

7) Belajar diperlancar bilamana peserta didik dilibatkan dalam proses belajar dan ikut bertanggung jawab terhadap proses belajar itu.

8) Belajar atas inisiatif sendiri yang melibatkan pribadi peserta didik seutuhnya, baik perasaan maupun 
intelek, merupakan cara yang dapat memberikan hasil yang mendalam dan lestari.

9) Kepercayaan terhadap diri sendiri, kemerdekaan, kreatifitas lebih mudah dicapai apabila peserta didik dibiasakan untuk mawas diri dan mengkritik dirinya sendiri, sedangkan penilaian orang lain merupakan cara kedua yang penting.

10) Belajar yang paling berguna secara sosial di dalam dunia modern ini adalah belajar mengenai proses belajar, suatu keterbukaan yang terus-menerus terhadap pengalaman dan penyatuannya ke dalam dirinya sendiri mengenai proses perubahan itu.

House (2006) menyatakan bahwa prestasi belajar matematika yang disebabkan karena faktor internal (kerja keras atau aktivitas) lebih baik dibandingkan prestasi belajar yang disebabkan karena faktor eksternal. Hal ini berarti aspek humanistik sangat berperan dalam keberhasilan pembelajaran matematika.

Era persaingan global seperti sekarang ini, membuat dunia pendidikan tinggi perlu untuk membekali lulusannya dengan karakter ataupun sikap yang mendukung keberhasilannya di masa depan. Permenristekdikti (2015) menegaskan bahwa salah satu sikap yang harus dimiliki oleh lulusan perguruan tinggi adalah sikap bertanggung jawab atas pekerjaan di bidang keahliannya secara mandiri.

Berangkat dari berbagai latar belakang tersebut, peneliti mencoba berperan dalam menganalisis aspek humanistik pada perangkat pembelajaran dan proses pembelajaran matematika diskrit, serta karakter tanggung jawab mahasiswa.

Rumusan masalah dari penelitian ini adalah (1) Bagaimana aspek humanistik pada perangkat pembelajaran matematika diskrit program studi manajemen informatika AMIK PGRI Kebumen, (2) Bagaimana aspek humanistik pada proses pembelajaran matematika diskrit program studi manajemen informatika AMIK PGRI Kebumen, (3) Bagaimana deskripsi karakter tanggung jawab mahasiswa semester III program studi manajemen informatika AMIK PGRI Kebumen.

Tujuan dari penelitian ini adalah (1) mendeskripsikan aspek humanistik pada perangkat pembelajaran matematika diskrit, (2) mendeskripsikan aspek humanistika pada proses pembelajaran matematika diskrit, (3) mendeskripsikan karakter tanggung jawab mahasiswa.

Adapun target khusus dari penelitian ini adalah (1) mengetahui perangkat pembelajaran (silabus, satuan 
acara perkuliahan, bahan ajar dan soal tes) yang digunakan (2) mengetahui proses pembelajaran yang dilakukan dosen dan mahasiswa (3) mengetahui karakter tanggung jawab mahasiswa.

\section{Metode}

Pendekatan dalam penelitian ini adalah pendekatan kualitatif. Penelitian ini berfokus pada deskripsi aspek humanistik pembelajaran matematika diskrit program studi manajemen informatika AMIK PGRI Kebumen tahun akademik 2015/2016 yang mencakup data mengenai: deskripsi aspek humanistik silabus, deskripsi aspek humanistik SAP (Satuan Acara Perkuliahan), deskripsi aspek humanistik bahan ajar, deskripsi aspek humanistik soal tes, deskripsi aspek humanistik proses pembelajaran yang dilakukan dosen, deskripsi aspek humanistik proses pembelajaran yang dilakukan mahasiswa, serta deskripsi karakter tanggung jawab mahasiswa.

Teknik pengumpulan data yang digunakan adalah observasi, wawancara, dan dokumentasi, yang digunakan untuk mengumpulkan data-data mengenai aspek humanistik perangkat pembelajaran, aspek humanistik proses pembelajaran dan karakter tanggung jawab mahasiswa. Temuan atau fakta-fakta yang didapatkan dideskripsikan dalam bentuk sajian data deskriptif, kemudian dianalisis (diinterpretasikan) secara kualitatif.

Dalam penelitian kualitatif ini, temuan atau data dapat dinyatakan valid (Sugiyono, 2009) apabila tidak ada perbedaan antara yang dilaporkan peneliti dengan apa yang sesungguhnya terjadi pada objek yang diteliti. Moleong (2011) berpendapat bahwa untuk menetapkan keabsahan data diperlukan teknik pemeriksaan. Pelaksanaan teknik pemeriksaan didasarkan atas sejumlah kriteria tertentu. Ada empat kriteria yang digunakan, yaitu derajat kepercayaan (credibility), keteralihan (transferability), ketergantungan (dependability), dan kepastian (confirmability).

Data yang didapatkan kemudian dianalisis dengan menggunakan teknik deskriptif kualitatif. Aktivitas analisis data penelitian ini menggunakan model Miles dan Huberman yang dalam (Sugiyono, 2009) meliputi: data reduction, data display, dan conclusion drawing/verivication.

\section{Hasil dan Pembahasan}

Hasil penelitian ini berupa deskripsi aspek humanistik perangkat pembelajaran (silabus, satuan acara perkuliahan, bahan ajar dan soal tes), deskripsi aspek humanistik proses pembelajaran serta deskripsi karakter tanggung jawab mahasiswa. 
Deskripsi aspek humanistik pada silabus bisa dilihat pada Tabel 1 berikut.

Tabel 1. Deskripsi aspek humanistik pada silabus

\begin{tabular}{ll}
\hline \multicolumn{1}{c}{ Indikator } & Kategori \\
\hline $\begin{array}{l}\text { Kompetensi Dasar (KD) yang } \\
\text { harus dicapai tidak memberatkan } \\
\text { mahasiswa. }\end{array}$ & $\begin{array}{l}\text { Sangat } \\
\text { Tinggi }\end{array}$ \\
$\begin{array}{l}\text { Pemilihan metode pembelajaran } \\
\text { lebih menekankan pada } \\
\text { pengembangan kreatifitas } \\
\text { mahasiswa misal diskusi dan }\end{array}$ & Tinggi \\
presentasi. & \\
$\begin{array}{l}\text { Pemberian tugas tidak hanya tugas } \\
\text { individu, namun juga tugas }\end{array}$ & Sedang \\
$\begin{array}{l}\text { kelompok yang dapat } \\
\text { menumbuhkan semangat belajar } \\
\text { dengan lingkungan sosialnya. }\end{array}$ & \\
$\begin{array}{l}\text { Pemberian tugas yang menggali } \\
\text { kreatifitas mahasiswa misalkan } \\
\text { presentasi ataupun tugas proyek. }\end{array}$ & Rendah \\
$\begin{array}{l}\text { Pemilihan sumber/bahan ajar tidak } \\
\text { menyulitkan mahasiswa untuk } \\
\text { mendapatkannya. }\end{array}$ & Tinggi \\
$\begin{array}{l}\text { Pemilihan urutan materi pokok } \\
\text { relevan dengan materi } \\
\text { sebelumnya. }\end{array}$ & Tinggi \\
$\begin{array}{l}\text { Penilaian pembelajaran tidak hanya } \\
\text { menekankan pada hasil tetapi juga } \\
\text { pada proses pembelajaran. } \\
\text { Modus }\end{array}$ & Tinggi \\
\hline & Tinggi \\
\hline
\end{tabular}

Tabel 1 menunjukkan bahwa aspek humanistik silabus masuk dalam kategori tinggi, namun ada satu indikator yang masih menunjukkan kategori rendah untuk aspek humanistik silabus yaitu indikator tentang pemberian tugas yang menggali kreatifitas mahasiswa misalkan presentasi ataupun tugas proyek.

Deskripsi aspek humanistik pada SAP (Satuan Acara Perkuliahan) bisa dilihat pada Tabel 2 berikut.

Tabel 2. Deskripsi aspek humanistik pada SAP

\begin{tabular}{|c|c|}
\hline Indikator & Kategori \\
\hline $\begin{array}{l}\text { Tujuan pembelajaran tidak } \\
\text { terlampau tinggi yang } \\
\text { menyebapkan tidak tercapainya } \\
\text { tujuan tersebut. }\end{array}$ & $\begin{array}{l}\text { Sangat } \\
\text { Tinggi }\end{array}$ \\
\hline $\begin{array}{l}\text { Bagian kegiatan pembelajaran } \\
\text { mencakup kegiatan fisik dan } \\
\text { mental. }\end{array}$ & Tinggi \\
\hline $\begin{array}{l}\text { Bagian kegiatan pembelajaran } \\
\text { melibatkan mahasiswa dalam } \\
\text { proses belajar bersama-sama } \\
\text { dengan lingkungan sosial misal } \\
\text { diskusi kelompok. }\end{array}$ & Tinggi \\
\hline $\begin{array}{l}\text { Bagian kegiatan pembelajaran } \\
\text { mendorong mahasiswa untuk } \\
\text { percaya diri, misal menyampaikan } \\
\text { pendapat, bertanya dan menjawab } \\
\text { pertanyaan. }\end{array}$ & Tinggi \\
\hline $\begin{array}{l}\text { Pemilihan urutan materi pokok } \\
\text { relevan dengan materi } \\
\text { sebelumnya. }\end{array}$ & Tinggi \\
\hline $\begin{array}{l}\text { Pemberian tugas yang menggali } \\
\text { kreatifitas mahasiswa misalkan } \\
\text { presentasi ataupun tugas proyek. }\end{array}$ & Rendah \\
\hline $\begin{array}{l}\text { Pemberian tugas tidak hanya } \\
\text { tugas individu, namun juga tugas } \\
\text { kelompok yang dapat } \\
\text { menumbuhkan semangat belajar } \\
\text { dengan lingkungan sosialnya. }\end{array}$ & Sedang \\
\hline $\begin{array}{l}\text { Penilaian pembelajaran tidak } \\
\text { hanya menekankan pada hasil } \\
\text { tetapi juga pada proses } \\
\text { pembelajaran. }\end{array}$ & Tinggi \\
\hline Modus & Tinggi \\
\hline
\end{tabular}

Tabel 2 menunjukkan bahwa aspek humanistik SAP (Satuan Acara Perkuliahan) masuk dalam kategori tinggi, namun ada satu indikator yang masih menunjukkan kategori rendah untuk aspek humanistik SAP yaitu indikator tentang pemberian tugas yang menggali kreatifitas mahasiswa misalkan presentasi ataupun tugas proyek.

Deskripsi aspek humanistik pada bahan ajar bisa dilihat pada Tabel 3 berikut. 
Tabel 3. Deskripsi aspek humanistik pada bahan ajar

\begin{tabular}{ll}
\hline \multicolumn{1}{c}{ Indikator } & Kategori \\
\hline $\begin{array}{l}\text { Kompetensi Dasar (KD) yang } \\
\text { harus dicapai tidak memberatkan } \\
\text { mahasiswa. }\end{array}$ & $\begin{array}{l}\text { Sangat } \\
\text { Tinggi }\end{array}$ \\
$\begin{array}{l}\text { Bahasa mudah dipahami sehingga } \\
\text { menimbulkan rasa percaya diri bagi } \\
\text { mahasiswa untuk belajar mandiri. }\end{array}$ & Tinggi \\
$\begin{array}{l}\text { Terdapat petunjuk yang } \\
\text { mengarahkan mahasiswa untuk } \\
\text { belajar secara runtut sesuai dengan } \\
\text { runtutan materi. }\end{array}$ & Tinggi \\
$\begin{array}{l}\text { Urutan materi bahan ajar relevan } \\
\text { dengan materi sebelumnya. }\end{array}$ & Tinggi \\
$\begin{array}{l}\text { Banyaknya materi pada bahan ajar } \\
\text { relevan dengan waktu yang } \\
\text { tersedia. }\end{array}$ & Tinggi \\
$\begin{array}{l}\text { Latihan-latihan soal yang ada pada } \\
\text { bahan ajar disusun runtut dari } \\
\text { tingkat kesukaran rendah sampai } \\
\text { tinggi. }\end{array}$ & Tinggi \\
\hline \begin{tabular}{l} 
Modus \\
\hline
\end{tabular} & \\
\hline
\end{tabular}

Tabel 3 menunjukkan bahwa aspek humanistik bahan ajar masuk dalam kategori tinggi dan tidak ada satupun indikator aspek humanistik bahan ajar yang termasuk kategori rendah.

Deskripsi aspek humanistik pada soal tes bisa dilihat pada Tabel 4 berikut.

Tabel 4. Deskripsi aspek humanistik pada soal tes

\begin{tabular}{ll}
\hline \multicolumn{1}{c}{ Indikator } & Kategori \\
\hline $\begin{array}{l}\text { Terdapat petunjuk yang } \\
\text { mengarahkan mahasiswa agar } \\
\text { mengerjakan soal dengan tepat. }\end{array}$ & Tinggi \\
$\begin{array}{l}\text { Terdapat petunjuk yang } \\
\text { mengarahkan mahasiswa agar } \\
\text { mengerjakan soal sesuai dengan } \\
\text { kemampuan masing-masing. }\end{array}$ & Tinggi \\
$\begin{array}{l}\text { Bahasa soal mudah dipahami } \\
\text { sehingga menimbulkan rasa } \\
\text { percaya diri bagi mahasiswa untuk } \\
\text { mengerjakannya. }\end{array}$ & Sedang \\
$\begin{array}{l}\text { Terdapat alternatif pilihan soal } \\
\text { yang bisa dipilih oleh mahasiswa } \\
\text { sesuai dengan kemampuannya. }\end{array}$ & Sedang \\
\hline
\end{tabular}

\begin{tabular}{lc}
\hline Materi soal relevan dengan materi & Tinggi \\
yang sudah dipelajari mahasiswa. & \\
$\begin{array}{l}\text { Banyaknya soal yang harus } \\
\text { dikerjakan relevan dengan waktu }\end{array}$ & Tinggi \\
yang tersedia. & \\
Modus & Tinggi \\
\hline
\end{tabular}

Tabel 4 menunjukkan bahwa aspek humanistik soal tes masuk dalam kategori tinggi dan tidak ada satupun indikator aspek humanistik soal tes yang termasuk kategori rendah.

Berdasarkan Tabel 1, Tabel 2, Tabel 3 dan Tabel 4 dapat dikatakan bahwa perangkat pembelajaran matematika diskrit yang digunakan oleh dosen sudah memasukkan aspek-aspek humanistik dengan kategori tinggi, walaupun masih terdapat satu indikator aspek humanistik yang masih rendah pada silabus dan SAP yaitu indikator tentang pemberian tugas yang menggali kreatifitas mahasiswa misalkan presentasi ataupun tugas proyek.

Deskripsi aspek humanistik pada proses pembelajaran yang dilakukan dosen bisa dilihat pada Tabel 5 berikut.

Tabel 5. Deskripsi aspek

humanistik pada proses pembelajaran yang dilakukan dosen

\begin{tabular}{ll}
\hline \multicolumn{1}{c}{ Indikator } & Kategori \\
\hline $\begin{array}{l}\text { Dosen memulai perkuliahan } \\
\text { dengan wajah ceria dan memberi } \\
\text { salam kepada mahasiswa. }\end{array}$ & Tinggi \\
$\begin{array}{l}\text { Dosen memberikan motivasi } \\
\text { belajar kepada mahasiswa. }\end{array}$ & Sedang \\
$\begin{array}{l}\text { Dosen menyampaikan apersepsi } \\
\text { tentang materi perkuliahan } \\
\text { sebelumnya. }\end{array}$ & Tinggi \\
\begin{tabular}{l} 
Dosen mengkondisikan kegiatan \\
\hline
\end{tabular} & Tinggi \\
\hline
\end{tabular}




\begin{tabular}{l|l}
\hline $\begin{array}{l}\text { pembelajaran agar mencakup } \\
\text { kegiatan fisik dan mental. }\end{array}$ & \\
\hline $\begin{array}{l}\text { Dosen mengkondisikan mahasiswa } \\
\text { dalam proses belajar agar bersama- }\end{array}$ & Tinggi \\
sama dengan lingkungan sosialnya & \\
misal diskusi kelompok. & \\
\hline $\begin{array}{l}\text { Dosen mengkondisikan mahasiswa } \\
\text { dalam proses belajar untuk percaya }\end{array}$ & Tinggi \\
diri, misal menyampaikan & \\
pendapat, bertanya dan menjawab & \\
pertanyaan. & \\
$\begin{array}{l}\text { Dosen memberikan tugas yang } \\
\text { menggali kreatifitas mahasiswa }\end{array}$ & Rendah \\
misalkan presentasi ataupun tugas & \\
proyek. & \\
$\begin{array}{l}\text { Dosen memberikan tugas yang } \\
\text { tidak hanya tugas individu, namun }\end{array}$ & Sedang \\
juga tugas kelompok yang dapat & \\
menumbuhkan semangat belajar & \\
dengan lingkungan sosialnya. & \\
\hline $\begin{array}{l}\text { Dosen mendesain kegiatan } \\
\text { pembelajaran agar relevan dengan } \\
\text { banyaknya waktu yang tersedia. }\end{array}$ & Tinggi \\
\hline \begin{tabular}{l} 
Modus \\
\hline
\end{tabular} & Tinggi \\
\hline
\end{tabular}

Tabel 5 menunjukkan bahwa aspek humanistik pada proses pembelajaran yang dilakukan dosen masuk dalam kategori tinggi, namun masih ada satu indikator yang masih rendah yaitu indikator tentang dosen memberikan tugas yang menggali kreatifitas mahasiswa misalkan presentasi ataupun tugas proyek.

Masih terdapatnya satu indikator aspek humanistik yang masih rendah pada proses pembelajaran yang dilakukan dosen sejalan dengan masih terdapatnya satu indikator aspek humanistik pada perangkat pembelajaran yang masih rendah yaitu indikator tentang pemberian tugas yang menggali kreatifitas mahasiswa misalkan presentasi ataupun tugas proyek. Hal ini dikarenakan perangkat pembelajaran tersebutlah yang menjadi pegangan dosen dalam mengajar, sehingga adanya indikator aspek humanistik yang masih rendah pada perangkat pembelajaran juga menyebapkan adanya indikator aspek humanistik yang masih rendah dalam proses pembelajaran yang dilakukan dosen.

Deskripsi aspek humanistik pada proses pembelajaran yang dilakukan mahasiswa bisa dilihat pada Tabel 6 berikut.

Tabel 6. Deskripsi aspek humanistik pada proses pembelajaran yang dilakukan mahasiswa

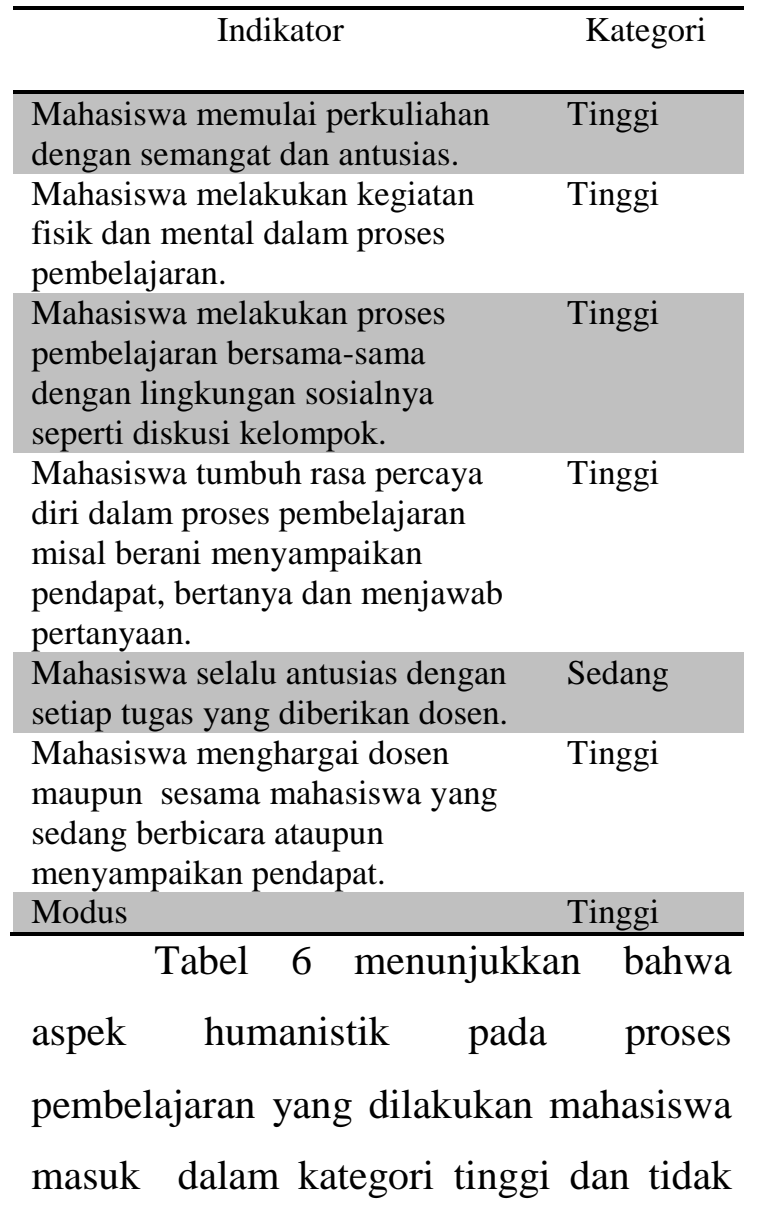


ada satupun indikator yang termasuk kategori rendah.

Berdasarkan Tabel 5 dan Tabel 6, secara umum aspek humanistik pada proses pembelajaran baik yang dilakukan dosen maupun mahasiswa masuk dalam kategori tinggi.

Deskripsi karakter tanggung jawab mahasiswa bisa dilihat pada Tabel 7 berikut.

Tabel 7. Deskripsi karakter tanggung jawab mahasiswa

\begin{tabular}{ll}
\hline Kategori & Persentase \\
\hline Sangat tinggi & $12,00 \%$ \\
Tinggi & $73,00 \%$ \\
Sedang & $15,00 \%$ \\
Rendah & $00,00 \%$ \\
Sangat rendah & $00,00 \%$ \\
Total & $100 \%$ \\
\hline
\end{tabular}

Tabel 7 menunjukkan bahwa karakter tanggung jawab mahasiswa masuk dalam kategori tinggi dan tidak ada yang masuk dalam kategori rendah atau dibawahnya. Aspek humanistik dosen disini sangat berkaitan. Menurut Rogers (Dalyono, 2012) salah satu prinsip pembelajaran humanistik yang penting ialah belajar diperlancar bilamana mahasiswa dilibatkan dalam proses belajar dan ikut bertanggung jawab terhadap proses belajar itu. Prinsip inilah yang menjadi salah satu dorongan bagi mahasiswa untuk bertanggung jawab dalam belajarnya dikarenakan mahasiswa merasa dilibatkan dalam belajarnya dan merasa bahwa dirinya menjadi bagian penting dalam proses pembelajaran tersebut.

\section{Simpulan dan Saran}

\section{Simpulan}

Berdasarkan data dan temuan penelitian tentang aspek humanistik pada perangkat pembelajaran dan proses pembelajaran matematika diskrit serta karakter tanggung jawab mahasiswa program studi manajemen informatika AMIK PGRI Kebumen dapat disimpulkan sebagai berikut:

1. Perangkat pembelajaran yang digunakan oleh dosen matematika diskrit program studi manajemen informatika AMIK PGRI Kebumen sudah memasukkan aspek-aspek humanistik dalam perangkat pembelajarannya dengan kategori tinggi. Adapun detailnya adalah sebagai berikut.

a. Pada silabus, aspek humanistiknya masuk kategori tinggi namun terdapat satu indikator yang masih rendah yaitu indikator tentang pemberian tugas yang menggali kreatifitas mahasiswa misalkan presentasi ataupun tugas proyek.

b. Pada SAP, aspek humanistiknya masuk kategori tinggi namun terdapat satu indikator yang masih rendah yaitu indikator tentang 
pemberian tugas yang menggali kreatifitas mahasiswa misalkan presentasi ataupun tugas proyek.

c. Pada bahan ajar, aspek humanistiknya masuk kategori tinggi dengan tidak ada satupun indikator yang masuk kategori rendah.

d. Pada soal tes, aspek humanistiknya masuk kategori tinggi dengan tidak ada satupun indikator yang masuk kategori rendah.

2. Proses pembelajaran yang dilakukan dosen sudah memasukkan aspek humanistik dengan kategori tinggi, namun masih ada satu indikator yang masih rendah yaitu indikator tentang pemberian tugas yang menggali kreatifitas mahasiswa misalkan presentasi ataupun tugas proyek. Proses pembelajaran yang dilakukan mahasiswa juga sudah memasukkan aspek humanistik dengan kategori tinggi dan tidak ada satupun indikator yang menunjukkan kategori rendah.

3. Karakter tanggung jawab mahasiswa semester III program studi manajemen informatika AMIK PGRI Kebumen berada pada kategori tinggi.

\section{Saran}

Saran yang dapat penyusun sumbangkan sehubungan dengan hasil penelitian ini adalah
1. Dosen hendaknya meningkatkan aspek humanistik yang masih rendah pada perangkat pembelajran khususnya pada silabus dan SAP yaitu tentang pemberian tugas yang menggali kreatifitas mahasiswa misalkan presentasi ataupun tugas proyek..

2. Dosen hendaknya meningkatkan aspek humanistik yang masih rendah pada proses pembelajaran yaitu tentang pemberian tugas yang menggali kreatifitas mahasiswa misalkan presentasi ataupun tugas proyek.

\section{Ucapan Terimakasih}

Ucapan terima kasih kami sampaikan kepada pihak-pihak yang telah membantu dalam penelitian ini diantaranya:

1. Rekan-rekan dosen dan segenap mahasiswa program studi manajemen informatika AMIK PGRI Kebumen yang telah berpartisipasi dalam penelitian ini.

2. Pihak-pihak lain yang telah membantu dalam penelitian ini namun tidak bisa disebutkan satu persatu.

\section{Daftar Pustaka}

Budiningsih, C.A. 2005. Belajar dan Pembelajaran. Jakarta:Rineka Cipta.

Dalyono, M. 2012. Psikologi Pendidikan. Jakarta: Rineka Cipta. 
Dimyati dan Mudjiono. 1999. Belajar dan Pembelajaran. Jakarta:Rineka Cipta.

House, J.D. 2006. Mathematics Beliefs and Achievement of Elementary School Students in Japan and the United States: Results From the Third International Mathematics and Science Study. The Journal of Genetic Psychology, 167(1): 31-45.

Junaedi dan Asikin. 2012. Pengembangan Pembelajaran Matematika
Humanistik Untuk Meningkatkan Kemahiran Matematis. UJMER 1 (2): 114-120.

Moleong, L.J. 2011. Metodologi Penelitian Kualitatif Edisi Revisi. Bandung: Rosdakarya.

Permenristekdikti. 2015. Standar Nasional Pendidikan Tinggi. Jakarta: Kemenristekdikti.

Sugiyono, 2009. Metode Penelitian Kuantitatif Kualitatif dan $R \& D$. Bandung: Alfabeta. 